\title{
LNG in the Asia-Pacific Region: Twenty Years of Trade and Outlook for the Future
}

by

\author{
Babak Kiani \\ Energy Program \\ Resource Systems Institute \\ East-West Center
}

\section{DISCLAIMER}

\begin{abstract}
This report was prepared as an account of work sponsored by an agency of the United States Government. Ncither the United States Government nor any agency thereof, nor any of their employees, makes any warranty, express or implied, or assumes any legal liability' or "esponsibility for the accuracy, completeness, or usefulness of any information, apparatus, product, or process disclosed, or represents that its use would not infringe privately owined rights. Reference herein to any specific commercial product, process, or service by trade name, trademark, manufacturer, or otherwise does not necessarily constitute or imply its endorsement, recommendation, or favoring by the United States Government or any agency thereof. The views and opinions of authors expressed herein do not necessarily state or reflect those of the United States Government or any agency thereof.
\end{abstract}




\section{EXECUTIVE SUMMARY}

- Only two decades ago, natural gas did not play a significant role in energy consumption in countries of the Asia-Pacific region. Since then, however, natural gas has become increasingly important in individual countries, substantially contributing to primary energy requirements in electricity generation, as well as residential/commercial energy consumption.

- Despite the existence of considerable natural gas reserves within the region, the natural gas trade did not evolve until the transport of natural gas in liquefied form became economical in the mid-1960s. With the major obstacle resolved, the region's vast natural gas reserves became accessible to international trade. As a result, LNG trade commenced between an increasing number of countries, allowing the utilization of valuable energy resources that, prior to that, had remained idle due to the lack of domestic markets and/or unfavorable economics.

In 1989, the Asia-Pacific region entered into the third decade of LNG trade. Since the commencement of LNG deliveries from the United States to Japan in 1969, volumes shipped within or to the region have increased substantially. The number of trade participants, too, increased rapidly, and, by 1990 , six countries within and outside of the region (the United States, Brunei, Abu Dhabi, Indonesia, Malaysia, and Australia, by order of market entrance) will export LNG to three Asia-Pacific countries (Japan, Korea, and Taiwan).

- In the economically most active countries of the region, the rapid increase in consumption of fossil fuels in the past has brought along serious environmental pollution, and has induced the search for alternative energy sources, as well as the enactment of strict emissions standards in the most densely populated areas of these countries. In effect, nuclear power and natural gas have been substituted for oil and coal within the power generation sector to a significant extent. In addition, electricity and natural gas utilization within the residential/commercial sectors are being actively promoted, opening further potential of substitution for oil and coal. 
- Future energy demand is expected to continue rising in the region. This, along with growing public opposition to new nuclear plants and increased coal utilization, suggests substantial potential for natural gas utilization. However, in the light of sufficient reserves and growing demand, much of the future prospects of natural gas in Asia-Pacific depends on institutional arrangements between current and potential buyers and sellers.

- In the past, LNG contracts regularly covered a period of 15 to more than 20 years. Neither the pricing principles, nor contractual quantities allowed for significant flexibility. As a result, and even though numerous renegotiations of contract terms took place in the case of all major contracts, the parties to each trade were virtually tied into the bilateral trade for the entire contract period.

- Along with changes in the basic market conditions, contracting practices have also changed. With both buyers and sellers becoming comparatively less dependent on single trading partners, due to the rise in the number of market participants, bargaining skills and experience, as well as strategic behaviour, have become increasingly important. In addition, the financial burden caused by multi-billion-dollar investments on the side of sellers has diminished to a substantial degree, thus allowing suppliers to calculate more competitively. Evidence exists, that the huge initial investments, even though sunk costs from the theoretical point of view and therefore irrelevant as far as actual pricing is concerned, do affect sellers' marketing behaviour. Several new, relatively shortterm contracts with reportedly very competitive prices seem to support this opinion.

- Currently, the market is standing at the crossroads. Stability and security of supplies are to be maintained. On the other hand, contractual relations are to be designed in a way that provides both sellers and buyers with a higher degree of flexibility. Pricing, take-or-pay obligations, and contract durations are only a few examples. Given the current and forecast demand-supply situation within the region, much of LNG's future prospects in Asia-Pacific depends on the ability and willingness of market participants to carefully balance both stability and flexibility requirements, rather than unduly stress short-term and/or longterm interests. 


\section{Table of Contents}

List of Tables $\ldots \ldots \ldots \ldots \ldots \ldots \ldots \ldots \ldots \ldots \ldots \ldots \ldots \ldots$

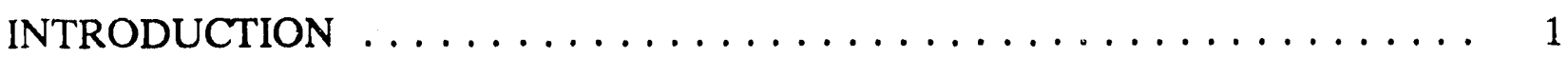

1. THE CURRENT STATUS OF LNG TRADE IN

THE ASIA-PACIFIC REGION $\ldots \ldots \ldots \ldots \ldots \ldots \ldots \ldots \ldots \ldots \ldots$

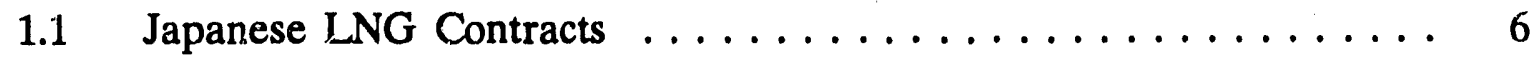

1.1.1 Overview of Japanese LNG Contracts . . . . . . . . . . . 6

1.1.2 The Role of Japanese Trading Houses . . . . . . . . . . . . . 13

1.2 Historical Overview of Korean LNG Imports . . . . . . . . . . . . 13

1.3 Historical Overview of Taiwanese LNG Imports . . . . . . . . . . . 14

2. PRESENT STRUCTURE AND PROJECTED DEMAND IN

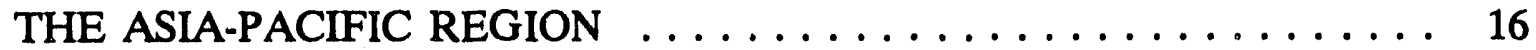

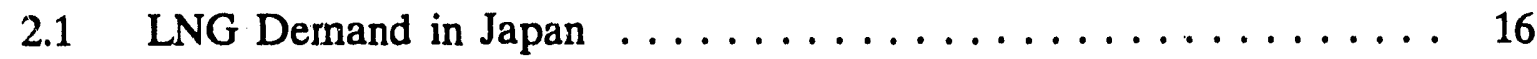

2.2 LNG Demand in Korea . . . . . . . . . . . . . . . . . 20

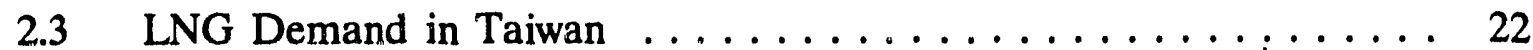

3. PROSPECTIVE AND TENTATIVE PROJECTS . . . . . . . . . . . . 26

4. LNG CONTRACTS: STABILITY VERSUS FLEXIBILITY $\ldots \ldots \ldots$

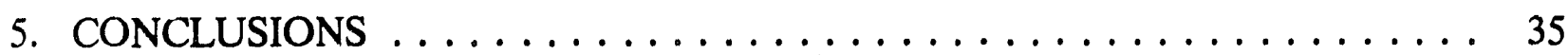

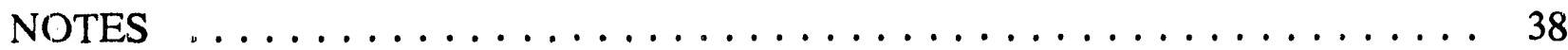




\section{List of Tables}

1.1 Japanese $\mathrm{LNG}$ Imports from Indonesia $\ldots \ldots \ldots \ldots \ldots$

1.2 Japanese LNG Imports from Countries other than Indonesia . . . . . . 4

$1.3 \quad$ LNG Imports in Korea and Taiwan . . . . . . . . . . . . . . . 5

1.4 Sources of Finance in Phase 1 of Arun and Badak LNG Plants . . . . 9

2.1 Forecasts of Japan's LNG Demand in $2000 \ldots \ldots$. . . . . . . . . . 19

2.2 Composition of Japan's LNG Demand in FY2000 . . . . . . . . . . 21

2.3 Projected LNG Demand in Korea: 1991-2010 . . . . . . . . . . . . . 23

2.4 Projection of Natural Gas Demand \& Supply in Taiwan: 1987-2000 . . 25

3.1 Tentative and Prospective LNG Plants Originating and/or Terminating in Asia-Pacific ............... 33 


\section{INTRODUCTION}

In only a quarter of a century, the international energy scene has witnessed a remarkable growth of trade in liquefied natural gas (LNG). Since the first cargoes of Algerian LNG were sent to the United Kingdom in 1964, the volume as well as the number of market participants have increased significantly. In 1987, LNG represented approximately 22.1 percent of the 253.65 billion cubic meters $\left(\mathrm{m}^{3}\right)$ of worldwide natural gas trade.' The Asia-Pacific region ${ }^{2}$ is the largest LNG market in the world and is characterized by several unique features. First, Japan, the region's predominant consumer of LNG, absorbs 70 percent of worldwide imports. ${ }^{3}$ Second, the region has substantial natural gas reserves and LNG capacity. Indonesia and Malaysia, the first and third largest LNG exporters in the world, respectively, account for more than 50 percent of global LNG supplies. Furthermore, the indigenous reserves of natural gas are capable of supporting additional LNC production. Third, the newly industrializing countries (NICs) that have been experiencing substantial growth in energy requirements are also becoming more aware of worsening environmental conditions. With relatively scarce indigenous energy endowments, these countries represent a substantial potential market for additional LNG supplies. Fourth, contracting practices in this region differ from those in other parts of the world. Financing, pricing, take-or-pay obligations, and buyers' involvement in project realizations are only a few examples. The terms of contractual arrangements between buyers and sellers have undergone significant changes, and this continuing evolution is likely to be a crucial factor in the future Asia-Pacific LNG trade. 
The purpose of this paper is to provide an overview of the Asia-Pacific LNG market, including the current status of LNG trade, and the future demand and supply prospects, as well as the examination of aspects related to project financing and contractual arrangements.

\section{THE CURRENT STATUS OF LNG TRADE IN THE ASIA-PACIFIC REGION}

Japan and South Korea (hereafter Korea) are the region's two importers of LNG. In 1987, Japanese and Korean imports amounted to 29.7 million and 0.4 million tonnes of LNG, respectively.

LNG is supplied from five sources, three from within the region, and two from outside. These are, by order of market entrance, the United States (Alaska), Brunei, Abu Dhabi, Indonesia, and Malaysia. At present, Indonesian LNG provides over 50 percent of LNG supplies to the region, with Malaysia and Brunei each reaching roughly a 20 percent share of LNG volumes. The United States and Abu Dhabi supply approximately 7 percent and 3 percent, respectively, of the Asia-Pacific LNG imports.

Australia will soon become the sixth LNG exporter to the region in the second half of 1989 , with contract volumes to Japan set at 5.8 million tonnes/year over a 19year period. In early 1990, Taiwan will become the Asia-Pacific's third LNG-importing nation. The contract with Indonesia indicates 1.5 million tonnes/year for 20 years. Tables 1.1-1.3 show currently operating LNG projects for the Far and Southeast Asian region. 


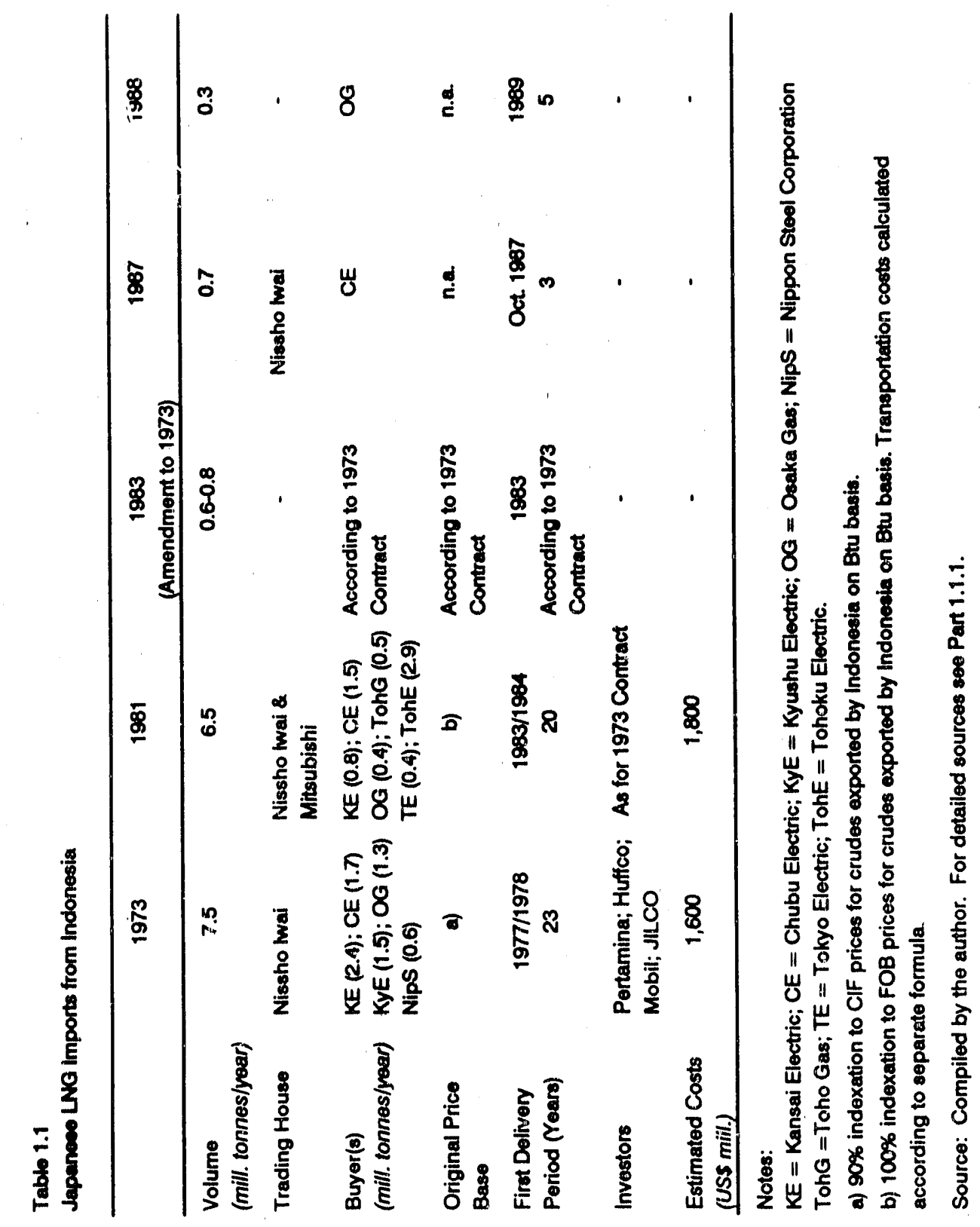




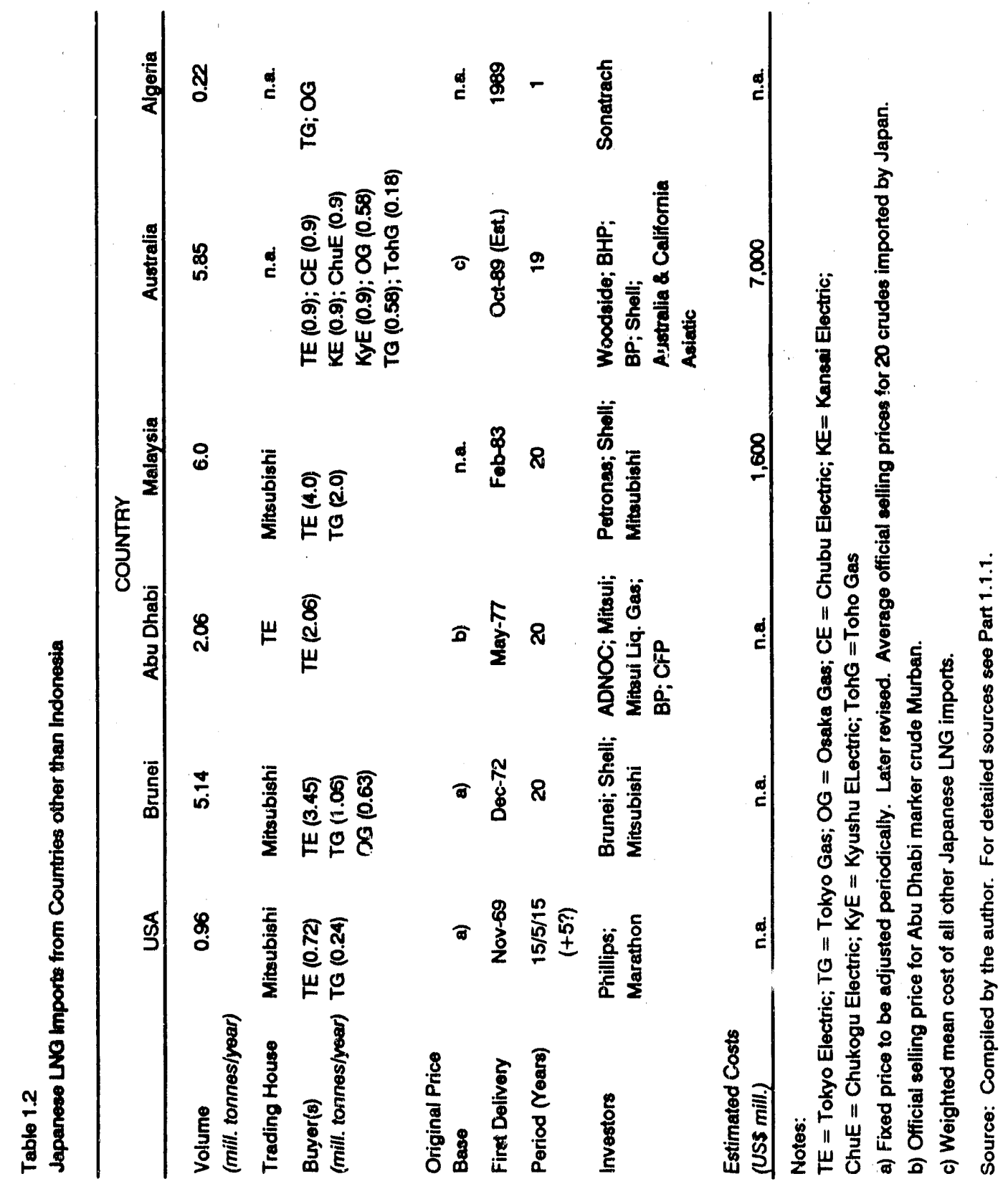


Table 1.3

LNG IMPORTS IN KOREA AND TAWAN

\begin{tabular}{|c|c|c|}
\hline & KOREA & TAWAN \\
\hline Source & Indonesia & Indonesla \\
\hline \multicolumn{3}{|l|}{ Volume } \\
\hline (mill. tonnes/year) & 2.0 & 1.5 \\
\hline Importer & Korea Gas Corp. & $\begin{array}{c}\text { Chinese Petroloum } \\
\text { Corp. }\end{array}$ \\
\hline Buyer(8) & Koroa Gas Corp. & $\begin{array}{c}\text { Chinese Potroleum } \\
\text { Corp. }\end{array}$ \\
\hline \multicolumn{3}{|l|}{ Orlginal Price } \\
\hline Base & n.a. & n.a. \\
\hline First Delivery & Oct-86 & 1990 \\
\hline Period (Years) & 20 & 20 \\
\hline Irivestors & Mobll Oil Indonesia & Huffco (?) \\
\hline \multicolumn{3}{|l|}{ Estimated Costs } \\
\hline (USS mill.) & 380 & 400 \\
\hline
\end{tabular}

Source: Complled by the author. For detailed sources 800 Parte 1.2 and 1.3. 


\subsection{Japanese LNG Contracts}

\subsubsection{Overview of Japanese LNG Contracts}

Alaska: In 1967, following negotiations with Marathon Oil and Phillips Petroleum, two Japanese utilities, Tokyo Gas and Tokyo Electric, signed contracts calling for an annual delivery of 960,000 tonnes of LNG from Cook Inlet, Alaska. Contracts were scheduled for start-up in $1969 .{ }^{4}$ The original contract period of 15 years, was extended for 5 more years in 1983 (1984-89), and renewed for another 15-year period in 1988 (1989-2004), with the option of a third extension of 5 years. ${ }^{5}$

The Alaskan deliveries are absorbed by Tokyo Gas and Tokyo Electric on a 1:3 basis. ${ }^{6}$ The original contracts reportedly called for a fixed price of US\$0.52 per million British thermal units (MMBTU), subject to periodic renegotiation. In the early 1980s, this was changed and LNG prices were linked to the mean cost of Japan's crude imports (CIF), on an Btu-equivalent basis. ${ }^{8}$ With the recent weakness in crude oil prices, particularly during 1985 and 1986, Alaskan LNG prices have followed the decline in crude prices, falling substantially from a peak of US\$5.94/MMBTU in 1981 to an average of US\$3.07/MMBTU for the period January-October 1988.

Brunei: The Sultanate of Brunei commenced LNG exports to Japan in 1972. Contracts signed between Brunei LNG Ltd., Mitsubishi Corporation, and Shell Petroleum N.V. as sellers, and Tokyo Electric, Tokyo Gas, and Osaka Gas as buyers, called for an annual delivery of over 5 million tonnes of LNG to the buyers' facilities over a 
20-year period. The first cargoes were delivered in $1972.9^{9}$ Reportedly, deliveries are made on the basis of a 70:20:10 split, respectively, for the above-mentioned buyers.

The Brunei LNG project is a joint venture between the Sultanate of Brunei, Mitsubishi, and Shell. The three are partners in Brunei LNG Ltd., which is the operator of the liquefaction facilities in Lumut. Brunei Coldgas Ltd., which is the marketing subsidiary, was established by Mitsubishi and Shell. However, in 1972, the Sultanate of Brunei took a one-third stake in this company. In 1986, the Sultanate's shared was raised to 50 percent, leaving Mitsubishi and Shell each with a 25 percent share. ${ }^{10}$ As with most LNG contracts, few details are available on the pricing of Brunei LNG. However, since spring 1980, prices have been related to the mean cost of Japan's crude oil imports (CIF) on an heat equivalent basis. ${ }^{11}$ This arrangement, along with sharply falling crude prices, resulted in substantial price reductions for volumes exported by Brunei. Prices have declined from a peak of US\$5.97/MMBTU in 1980 to an average of US\$3.18/MMBTU for the first nine months of 1988.

Abu Dhabi: LING exports from Das Island to Japan commenced in 1977. The Abu Dhabi-Japan contract calls for an annual delivery of 2 million tonnes to Tokyo Electric for a 20-year period. ${ }^{12}$ Abu Dhabi Gas Liquefaction Company (ADGLC), the seller, was established as a joint venture between Abu Dhabi National Oil Company (ADNOC, 51 percent), Mitsui of Japan (22.05 percent), British Petroleum (16.33 percent), Compagnie Française des Pétroles (CFP, 8.17 percent) and Mitsui Liquefied Gas $(2.45$ percent $){ }^{13}$ In addition to the above-mentioned LNG volumes, 800,000 
tonnes/year of Natural Gas Liquids (NGLs) are delivered to the Japanese buyer as well.

The original contract linked LNG prices to the heat equivalent FOB price of Abu Dhabi's Murban crude. A freight component was added to convert to a heat equivalent CIF price for Japan. ${ }^{14}$ Since 1982 , this formula has been changed. Although no confirmation is available, it is assumed that as prices for almost all Japanese LNG imports have been linked to the mean cost of Japan's crude imports (CIF) since the early 1980s, the same holds true for LNG imports from Abu Dhabi. In contrast to their peak of US\$6.57/MMBTU in 1981, prices for Abu Dhabi LNG have fallen to US\$3.30/MMBTU for the period January-October 1988.

Indonesia: Indonesia is the largest LNG exporter in the world. Currently, Iıdonesian LNG is produced in two plants: Arun in Northern Sumatra and Badak in East Kalimantan. More than 90 percent of the LNG is exported under long-term contracts.

The first contract, signed in 1973, called for delivery of 7.5 million tonnes/year of LNG over a 23-year period, beginning in 1977. P'yers are Chubu Electric (1.7 million tonnes/year), Kansai Electric (2.4 million tonnes/year), Kyushu Electric (1.5 million tonnes/year), Osaka Gas (1.3 million tonnes/year), and Nippon Steel Corporation (0.6 million tonnes/year). The required investment on the Indonesian side has been estimated at about US\$1.6 billion, the biggest part of which (US\$1.4 billion) has been provided through Japanese sources (see Table 1.4). 
Tablo 1.4

Sources of Finanoe in Phees 1 of Arun and Badak LNO Plants

(1973 Contract)

\begin{tabular}{|c|c|c|}
\hline Source of Funds & $\begin{array}{c}\text { Currency and Intermediary } \\
\text { Inetitution }\end{array}$ & $\begin{array}{l}\text { Amount } \\
\text { (USS mill.) }\end{array}$ \\
\hline \multicolumn{3}{|l|}{ EXIM Bank and Japaneses } \\
\hline Private Banke & USS; JILCO & 1,120 \\
\hline Japanees LNG Buyere & YEN; JILCO & 91 \\
\hline \multicolumn{3}{|l|}{ Japanese Government; } \\
\hline \multicolumn{3}{|l|}{ Overean Economic } \\
\hline Cooperation Fund (OECF) & YEN; Bank Indoncia & 187 \\
\hline Indonesian Governmant & US\$; Bank Indoneela & $\mathbf{8 0}$ \\
\hline Indoneasian Government & RP; Banki Indoneala & 91 \\
\hline International Commercial Banks & USs; Bank Indoneala & 50 \\
\hline \multicolumn{3}{|l|}{ Total Funds Including Intereet } \\
\hline During Construction Period & & 1,638 \\
\hline
\end{tabular}

Sourco: Hittapew R.O., "Financing of Netural Ges Export Projects in Developing Countries -The Indonestan Exporionce-', paper precemted at the "Elghth International Conference on Liquefied Natural Ges", 15-19 June 1986, Los Angeles, U.S.A. 
While the original contract called for LNG prices (CIF) to be equivalent to the average of the official selling prices (OSP) for a basket of Indonesian crudes on a thermal equivalent basis, ${ }^{\text {is }}$ it was announced in February 1989 that prices would be linked to actual selling prices. ${ }^{16}$ Reportedly, this contract was the first in the AsiaPacific LNG trade to include take-or-pay obligations. The only information available regarding the extent of such obligations in Indonesian contracts indicates a range of 310 percent of the annual contract volumes. In addition, this contract called for a "floor price," a currency adjustment clause, a minimum Btu content per delivery and per year, respectively, and the seller's obligation to first offer all volumes produced in excess of contract volumes to the above-mentioned buyers. ${ }^{17}$

The second contract, signed in 1981, called for an annual delivery of 6.5 million tonnes to eight Japanese utilities (Tokyo Electric, Tohoku Electric, and Toho Gas were added to the buyers already named in the 1973 contract) over 20 years. Unlike the first contract that used a CIF basis, the second contract tied the FOB price of LNG to the basket of Indonesian crudes and increased the price linkage from the previous 90 percent to 100 percent. ${ }^{28}$ Furthermore, required funding that was reportedly as high as US\$1.8 billion was provided by Japanese prepayments for LNG volumes to be delivered over the next ter years. ${ }^{19}$ Unfortunately, no detailed information on the financial arrangements is available. It is assumed that the fixed annual amounts that have been agreed on take into account fluctuations in the LNG price.

Both the Arun and Badak plants have been operating in excess of their design capacities for several years. According to the 1973 contract, extra volumes have been 
offered to the buyers, and have usually been accepted. In 1983 , the contracts were specifically revised, calling for additional volumes of 600,000 to 800,000 tonnes/year to be delivered to the buyers of the 1973 contract until its expiration in the year $2000 .^{20}$ More recently Japanese buyers have signed two comparatively short-term LNG contracts. Chubu Electric has signed a contract with Pertamina calling for the delivery of 2.12 million tonnes of LNG during the period October 1987-Decemeber 1990. Reportedly, this contract does not include any take-or-pay obligation on the buyer's side. $^{21}$ Osaka Gas and Pertamina agreed on a volume of 1.5 million tonnes of LNG to be delivered within five years beginning in $1988 .^{n}$

Malaysia: Deliveries of LNG from Malaysia's Bintulu plant began in 1983. An agreement for the export of 6 million tonnes of LNG/year from Bintulu to Japan was made between the sellers, Petronas, Shell International Gas, and Mitsubishi Corporation, and the buyers, Tokyo Electric and Tokyo Gas. ${ }^{23}$ Delivered volumes are split between the buyers on a 2:1 basis, respectively. The total investment costs are estimated at US\$1.6 billion. Roughly half of these costs were provided through national sources with the other half through international sources (Eurodollar markets). ${ }^{24}$ Although there is no information available on individual contract clauses, reported prices have declined from their high of US\$5.18/MMBTU in 1983 to an average of about US\$3.30/MMBTU for the first nine months of 1988 . 
Algeria: Algeria's Sonatrach signed a short term contract with Tokyo Gas and Osaka Gas, calling for delivery of approximately 220,000 tonnes of LNG during $1989 . .^{25}$ Although no detailed information on this contract has been disclosed, it is believed that the price basis is very competitive. To what extent this type of short-term agreement can be interpreted as an indicator of future contracting practices in Asia-Pacific LNG trade is not yet clear. However, for reasons that will be discussed in a later section, a fundamental shift from long-term to short-term contracts does not seem to be very likely.

Australian North West Shelf Project: The Australian North West Shelf Project is scheduled for start-up in October 1989. The contract period is set for 19 years. Annual volumes of 5.85 million tonnes of LNG are to be delivered to eight Japanese utilities: Tokyo Electric (15.4 percent); Chubu Electric (15.4 percent); Kansai Electric (15.4 percent); Chugoku Electric (15.4 percent); Kyushu Electric (15.4 percent); Tokyo Gas (10 percent); Osaka Gas (10 percent); and Toho Gas ( 3 percent). Woodside Petroleum; BHP Petroleum Pty. Ltd.; BP Developments Australia Ltd.; California Asiatic Oil Company (a Chevron affiliate company); Shell Development (Australia) Pty. Ltd., and Japan Australia LNG (MIMI) Pty. Ltd. (jointly established by Mitsubishi Corporation and Mitsui \& Co. Ltd., which are partners in this $\mathrm{A} \$ 10$ billion project, each have a one-sixth share. ${ }^{26}$ Unfortunately, not much information is available on this contract. Prices are to follow fluctuations in all other Japanese LNG import prices, which means linkage to Japan's average (CIF) crude oil import costs. ${ }^{27}$ The existence 
of take-or-pay obligations has been confirmed by project participants, but no information regarding their extent has been given. ${ }^{28}$

\subsubsection{The Role of Japanese Trading Houses}

One of the unique features of the Japanese LNG trade is the involvement of large trading houses in contract negotiations as well as in subsequent transactions. As of 1987 , only 2.7 million tonnes/year of contracted volumes of 29.56 million tonnes/year did not involve Japanese trading companies. ${ }^{29}$ All other contracts were negotiated by Nissho Iwai (11.5 million tonnes/year), and Mitsubishi Corporation (15.4 million tonnes/year).

While in the early years, an important reason for the involvement of trading houses may have been a lack of experience in international negotiations and the development of large-scale international gas projects on the side of Japanese utilities, it can be assumed that their involvement has also facilitated the provision of required funds, both to Japanese utilities, as well as to exporters. Here, the well-known interrelations among Japanese trading houses, financial institutions, manufacturers, as well as their close cooperation with the government, may have been major factors contributing to the rapid development of Japan's LNG imports.

\subsection{Historical Overview of Korean LNG Imports}

Having declared a reduction in the economy's overall oil dependency as a major target for its national energy policy, Korea has achieved substantial progress regarding 
diversification of both energy and supply sources. As part of this policy, natural gas was introduced to the domestic market in 1986 with the arrival of the first cargo of Indonesian LNG of some 57,000 tonnes. According to contracts signed in 1983, Pertamina, Indonesia, will deliver 2 million tonnes of LNG/year to Korea Gas Corporation's (KGC) facilities at Pyongtaek over a period of 20 years.

The required investment for expansion of the Indonesian plant was reportedly about US $\$ 380$ million and was provided by Mobil Oil Indonesia. ${ }^{30}$ On the buyer's side, the investment is estimated at US\$550 million for the receiving and regasification facilities provided by $\mathrm{KGC}^{31}$ Original contracts reportedly called for the indexation of LNG prices to the CIF prices for Indonesian crudes sold to Korea. These provisions were subject to renegotiations in 1986, and the available information suggests that the LNG price was indexed to a basket of 20 Indonesian crudes. ${ }^{32}$ This pricing basis may again be revised in the near future, following Indonesia's adoption of price linkage to actual, rather than official selling prices..$^{33}$ Due to the short history of operation of the Korean project, little historical data are available with regard to price fluctuations. With the exception of the first trial deliveries, the March 1987 price of US\$3.40/MMBTU (CIF) indicates that these prices were in line with those for deliveries under other contracts.

\subsection{Historical Overview of Taiwanese LNG Imports}

Taiwan will become the newest country to import LNG. Facing rapid depletion of indigenous gas reserves, negotiations about LNG imports began as early as 1978 . In 
March 1987, an agreement was signed for the delivery of 1.5 million tonnes of LNG per year to new receiving and related facilities at Hsingta from an additional liquefaction train at Badak, Indonesia, for a period of 20 years. $^{34}$

The investments in Badak for the additional train were reported to be in the vicinity of US\$400 million. ${ }^{33}$ Most probably the funds were provided by Huffco, the Production Sharing Contract partner (PSC) at Badak. Funds required for the facilities at Hsingta have been reported to be as high as US\$920 million, but no information is available as to how this amount has been raised. ${ }^{36}$

Under the present plan, imports will begin in June 1989 with regular shipments to start in 1990 . Within two years, annual deliveries are expected to reach the full contract volumes.

The contract includes a number of flexibility clauses, including "allowances" that provide the option to increase or decrease deliveries by two shipments per year. The maximum number of allowances is four. Additional shipments can be incorporated into contract volumes, bringing them up to 1.62 million tonnes/year. There is also a takeor-pay clause that commits Taiwan to take (or pay for) at least 64 percent of the annual contract volumes during the buildup period (not including extra quantities). The basic price, which is reported to have been around US\$3.20/MMBTU in early 1987 (CIF), is 90 percent indexed to Indonesian crude export prices, with the remaining 10 percent following a transportation formula, including fixed escalation factors. ${ }^{37}$ 


\section{PRESENT STRUCTURE AND PROJECTED DEMAND IN THE ASIA-PACIFIC}

REGION

\subsection{LNG Demand in Japan}

In Japan, LNG is predominantly used for electricity generation unlike LNG/natural gas utilization patterns in other OECD member countries. Hence, developments in the electricity generating sector, and to a lesser extent developments in the town gas sector, will be crucial to future LNG prospects in Japan.

In 1987, the Ministry of International Trade and Industry (MITI) published a downward revision of its 1983 "Long-Term Energy Supply and Demand Outlook."138 According to this revision, the total energy requirement is to increase at an annual rate of 1.4 percent during the period 1986-95, reaching 490 million kilolitres (kl). During the subsequent five-year period, energy consumption is projected to rise 2 percent per year, totalling 540 million $\mathrm{kl}$ by the year 2000 .

Electricity generation during the period $1986-95$ is forecast to increase at an annual rate of 2.6 percent, reaching 760 Terawatt hours (TWh). Between 1995 and 2000 , electricity generation will rise by slightly more than 2.7 percent per year. By the year 2000 , total electricity generation is estimated at $868 \mathrm{TWh}$. The share of nuclear in power generation is expected to increase steadily from 35 percent in 1995 to 40 percent in 2000. Electricity generated in LNG-fired plants will increase from 130.4 TWh in 1986 to $164 \mathrm{TWh} /$ year for the period 1995-2000, and is expected to account for 20 percent of total electricity generation during the remainder of this century. The share of electricity produced from coal-fired plants is estimated to expand from 9.4 
percent in 1986 to 14 percent in 2000 . Hydroelectricity is projected to provide 15 percent in 2000, compared with 17.2 percent in 1986 . The share of oil- and LPGbased electricity is forecast to decrease sharply from nearly 24 percent in 1986 to 11 percent in 2000. With coal-generated electricity's share increasing to 14 percent in 2000 from 9.4 percent in 1986, and hydro electricity remaining relatively constant (17.2 percent in 1986, and 15 percent in 2000), oil and LPG are forecast to decrease sharply from nearly 24 percent in 1986 to 11 percent in 2000 . Projections of installed capacities for electricity generation in 2000 show nuclear plants accounting for 25 percent of total capacity, up from 16.2 percent in 1986. Coal-fired plants are expected to account for 11 percent in 2000 , compared to 7.4 percent in 1986 . The shares of LNG-fired and hydropower capacity are estimated to rise from 18.5 percent and 21.9 percent, respectively, in 1986 to 20 percent and 22 percent of total installed generation capacity in 2000. Oil/LPG capacity is projected to decline from 36 percent in 1986 to 22. percent in 2000 .

It is important to note the differences between the projected shares of generation capacity and shares of e'ectricity generation. In analyzing these figures, one important fact must be kept in mind. As part of its efforts toward a more diversified and more secure energy supply structure, Japan has installed dual- and triple-fired facilities (the so-called "Flexible Switching System") in order to facilitate switching from one fuel to another in case of a supply shortfall in one fuel. This strategy, along with the fact that in Japan baseload electricity generation is basically borne by nuclear, hydro and large-scale coal-fireci plants, explains the differences between installed 
capacities and electricity generation. In summary, nuclear power is designated to become the major baseload supplier of electricity, followed by coal and hydro as complimentary baseload electricity sources. LNG, in contrast, is to be the major intermediate load electricity supplier. Oil-based generation capacity is to be used solely for peak load.

As of early 1989, projections made by Japanese and non-Japanese sources estimated Japan's LNG demand in FY2000 to be in the range of 35 to 43 million tonnes/year (Table 2.1). However, with the postponement of 5,000-10,000 MW of additional nuclear capacities almost certain, ${ }^{39}$ these projections seem to be rather conservative. Depending on which strategy is chosen by Japanese utilities in compensating for these capacities, LNG demand for power generation could easily be much higher than currently projected. For instance, given the projected LNG-fired capacity of $43,000 \mathrm{MW}$ by 1995 , and assuming the average utilization rate of the mid1980s (approximately 50 percent), the LNG requirement for electricity generation will be approximately 32 million tonnes/year. Contract volumes in effect for 2000 , assuming renewal of the currently existing Abu Dhabi and Brunei contracts, will provide 34 million tonnes/year. Thus LNG demand for town gas and industrial fuel use in excess of 2 million tonnes/year must be met from new contracts. Town gas and industrial use accounted for 8.8 million tonnes/year in 1987 and consumption is expected to rise. ${ }^{40}$ As a result, supply shortages in the latter half of the 1990 s seem to be inevitable if additional volumes are not secured during the next few years. 
Table 21

Forecasts of Japan's LNG Demand in 2000

(mill. tonnes/year)

\begin{tabular}{|c|c|c|c|c|c|}
\hline & (1) & (ii) & (iii) & (bv) & (v) \\
\hline Demand & 43.1 & 43.0 & 38.0 & $37.4-40.8$ & 34.9 \\
\hline \multicolumn{6}{|l|}{ Supply } \\
\hline - Contracted Volumeo & 26.8 & 26.8 & 26.8 & 26.8 & 26.8 \\
\hline SURPLUS (DEFICT) & (16.3) & $(16.2)$ & $(11.2)$ & $(10.6-14.1)$ & (8.1) \\
\hline - Contract Renewale & & & & & \\
\hline - Brunei & 5.1 & 5.1 & 5.1 & 5.1 & 5.1 \\
\hline - Abu Dhabl & 2.1 & 2.1 & 2.1 & 2.1 & 2.1 \\
\hline SURPLUS (DEFICT) & $(9.1)$ & $(9.0)$ & $(4.0)$ & $(3,4-6,0)$ & $(0.9)$ \\
\hline
\end{tabular}

Notes:

(i) 'Long-Term Energy Supply and Demand Outlook', MITI, 14 Ootobur 1987.

(ii) Institute of Enorgy Economics, Tokyo, 1987.

(iii) Supply and Demand Committee of the Overall Energy Counoil, 1987.

(iv) Shell Kosan, Tokyo, June 1988.

(v) Petroleum Association of Japan, Tokyo, August 1987.

Source: Llsa Totto and Fereidun Feaharakl, 'Japan'o Future Energy Balance:

Room for Now LNG Import Contracte?", Petroleum Advisory No. 32 ,

29 A' sgust 1988, Energy Program, Resource Systems Institute,

East-West Conter, Honolulu, Hawall. 
The delays in Japan's nuclear program will increase demand for other power generation fuels. Due to worsening environmental pollution and the enactment of strict emissions standards for metropolitan areas, the substitution of coal-fired plants for postponed nuclear power plans does not seem very likely. If the Japanese decide to raise the utilization of LNG-fired capacity above 50 percent, the supply/demand gap could widen considerably (see Table 2.2). LNG demand for power generation alone could easily be as high as 35 million tonnes/year (55\% capacity utilization rate). The corresponding supply deficit could be as large as 10-14 million tonnes/year depending on the growth in demand in the town gas and industrial sectors. As a matter of fact, a number of Japanese utilities already announced early in 1989 upward revisions of their LNG utilization plans. ${ }^{41}$ In view of this new data, LNG demand in Japan around the turn of the century is projected to be in the range of 44 to 48 million tonnes/year.

\subsection{LNG Demand in Korea}

Korea received its first deliveries of Indonesian LNG in 1986. According to the Korea Energy Economics Institute (KEEI), ${ }^{2}$ the share of LNG in total primary energy supply is forecast to rise from 0.1 percent in 1986 to 4 to 5 percent in 2010 .

Projections for the years around the turn of the century indicate an import requirement for LNG of 2 million tonnes/year, the volume contracted for in the first agreement with Indonesia. Along with an increase in primary energy requirements from 61 million tonnes of oil equivalent (toe) in 1986 to about 170 million toe in 2010, LNG demand 
Table 22

Composition of Japan's LNG Demand in FY2000

\begin{tabular}{|c|c|c|c|c|c|c|c|c|}
\hline \multirow{2}{*}{$\begin{array}{l}\text { Uvill. } \\
\text { Rate } \\
\text { (a) }\end{array}$} & \multirow{2}{*}{$\begin{array}{l}\text { Electricity } \\
\text { Generation } \\
\text { ('000 MMH) }\end{array}$} & \multicolumn{3}{|c|}{ Demand ('000 tonnee) } & \multirow{2}{*}{$\begin{array}{l}\text { Contracte } \\
\text { (Scenario I) }\end{array}$} & \multirow{2}{*}{$\begin{array}{l}\text { Surplual } \\
\text { Defictt }\end{array}$} & \multirow{2}{*}{$\begin{array}{l}\text { Contraots } \\
\text { (Scenario II) }\end{array}$} & \multirow{2}{*}{$\begin{array}{l}\text { Surplus/ } \\
\text { Deficit }\end{array}$} \\
\hline & & Electricity & $\begin{array}{l}\text { Town Gas } \\
\text { \& Industry } \\
\text { (b) }\end{array}$ & TOTAL & & & & \\
\hline 0.40 & 150,672 & 25,319 & 8,800 & 34,119 & 26,840 & $-7,279$ & 34,040 & -79 \\
\hline 0.45 & 169,506 & 28,484 & 8,800 & 37,284 & 26,840 & $-10,444$ & 34,040 & $-3,244$ \\
\hline 0.50 & 188,340 & 31,648 & 8,800 & 40,448 & 26,840 & $-13,608$ & 34,040 & $-6,408$ \\
\hline 0.55 & 207,174 & 34,813 & 8,800 & 43,613 & 28,840 & $-16,773$ & 34,040 & $-9,573$ \\
\hline 0.60 & 226,008 & 37,978 & 8,800 & 46,778 & 26,840 & $-19,938$ & 34,040 & $-12,738$ \\
\hline
\end{tabular}

Notes:

(a) Installod LNG-fired capacity io projocted at 43,000 MW.

(b) LNG demand for town gas and industrial use is projocted to increase af 1.2\% p.a. between 1987 and 2000.

Scenario 1 : Aseumes Brunel and Abu Dhabl contracto are not renewed.

Scenario II : Assumes Brunol and Abu Dhabl contracte are renewed.

\begin{tabular}{|c|c|c|c|c|c|c|c|c|}
\hline \multirow{2}{*}{$\begin{array}{l}\text { Util. } \\
\text { Rate } \\
\text { (a) }\end{array}$} & \multirow{2}{*}{$\begin{array}{l}\text { Electricity } \\
\text { Generation } \\
(000 \mathrm{MWh})\end{array}$} & \multicolumn{3}{|c|}{ Demand ('000 tonnes) } & \multirow{2}{*}{$\begin{array}{l}\text { Contracts } \\
\text { (Scenario I) }\end{array}$} & \multirow{2}{*}{$\begin{array}{l}\text { Surpluar } \\
\text { Doficit }\end{array}$} & \multirow{2}{*}{$\begin{array}{l}\text { Contracts } \\
\text { (Scenario II) }\end{array}$} & \multirow{2}{*}{$\begin{array}{c}\text { Surplus/ } \\
\text { Deficit }\end{array}$} \\
\hline & & Electricity & $\begin{array}{c}\text { Town Gas } \\
\text { a Industry } \\
\text { (b) }\end{array}$ & TOTAL & & & & \\
\hline 0.40 & 150,672 & 25,319 & 12,800 & 38,119 & 26,840 & $-11,279$ & 34,040 & $-4,079$ \\
\hline 0.45 & 169,506 & 28,484 & 12,800 & 41,284 & 26,840 & $-14,444$ & 34,040 & $-7,244$ \\
\hline 0.50 & 188,340 & 31.648 & 12,800 & 44,448 & 26,840 & $-17,608$ & 34,040 & $-10,408$ \\
\hline 0.55 & 207,174 & 34,813 & 12,800 & 47,613 & 26,840 & $-20,773$ & 34,040 & $-13,573$ \\
\hline 0.60 & $226,0,028$ & 37,978 & 12,800 & 50,778 & 26,840 & $-23,938$ & 34,040 & $-16,738$ \\
\hline
\end{tabular}

Notes:

(a) Installed LNG-fired capacity is pinjected at 43,000 MW.

(b) LNG demand for town gas and indurtrinal use is projected to increase at $5 \%$ p.a.

between 1987 and 2000 .

Scenario 1: Aseumes Brunol and Abu Dhabi contracte are not renewed.

Scenario II : Asoumes Brunel and Abu Dhabi contracto are renewed.

Source: Liea Totto and Fereldun Fesharakl, 'Uapan's Future Energy Balance: Room for Now LNO Import Contracte?", Petroloum Advisory No. 32, 29 August 1988, Energy Program, Resource Systems Inetitute, East-West Center, Honolulu, Hawail.

Author's calculations.

Note: Tokyo Gas Co. has predicted LNG supllies from Pacific Rim Countries to fall short of demand in the East Asian region by 4.5 million tonnes by the year 2000. Demand is forecast to be as high as 57 million connes/year (48 mill. tonnes Japan; 5 mill. tonnes Korea; and 4 mill. tonnes Taiwan).

Platt's Global Alert, Oct. 25, 1889. 
has been forecast to rise to 5 to 7.5 million tonnes/year around 2010. Table 2.3 presents official demand forecasts and import requirements to 2010.

By the late 1990s, LNG demand may prove to be significantly higher than currently projected levels due to the uncertain future development of the nuclear power sector. According to present plans, by the turn of the century the residential and commercial sectors will be by far the most important LNG consumers in Korea with a share of 70 to 80 percent, followed by the industrial and power generation sectors. In particular, LNG demand for power generation could prove to be much higher than projected. Environmental concerns will limit significant increases in coal consumption as well as generation from new nuclear plants. In particular, from the year 2000 onwards, import requirements may be as high as 10 million tonnes/year in comparison to the earlier forecast of 5 to 7.5 million tonnes/year. In fact, recent talks between Malaysian and Korean authorities regarding LNG deliveries of about 1.5 million tonnes/year from Malaysia suggest that the latest official demand projections are already considered too conservative. ${ }^{*}$ For these reasons, Korea's LNG demand by the turn of the century is projected to be about 3 to 4 million tonnes/year in this report.

\subsection{LNG Demand in Taiwan}

In Taiwan, natural gas consumption is forecast to rise to 4.3 billion $\mathrm{m}^{3}$ in 2000 , of which 2.9 billion $\mathrm{m}^{3}$ are to be imported ${ }^{\mu}$ This translates into securing LNG supplies of about 2.1 million tonnes/year by the end of the century. Natural gas will be reintroduced to the power generation sector with the commencement of LNG imports 
Table 23

Projected LNG Demand in Korea: 1391-2010 (cooo tonnes)

\begin{tabular}{|c|c|c|c|}
\hline & 1991 & 2001 & 2010 \\
\hline \multicolumn{4}{|l|}{ Rosidontial and } \\
\hline Commercial & $240-302$ & $1,577 \cdot 2,589$ & $3,457-4,182$ \\
\hline Industrial & $172-180$ & 430.771 & 2491,652 \\
\hline \multicolumn{4}{|l|}{ Power } \\
\hline Generation & $1,600-1,670$ & 0,330 & $641-1,654$ \\
\hline TOTAL & $2,012-2,152$ & $2,007-3,699$ & $5,047 \cdot 7,398$ \\
\hline \multicolumn{4}{|l|}{ Import } \\
\hline Requirement & $2,012-2,152$ & $2,007-3,699$ & $5,047-7,398$ \\
\hline
\end{tabular}

Source: KEEI, 1987. 
scheduled for 1990. Natural gas was formerly a fuel source for power generation, but this operation was interrupted in 1977 because of the rapid depletion of indigenous gas reserves.

As a result of the decision to import LNG, the structure of natural gas consumption in Taiwan will change significantly. In 1987, the residential and commercial sectors absorbed almost 570 million $\mathrm{m}^{3}$, or 54 percent of overall natural gas consumption. During the first half of the 1990s, the share of the residential and commercial sectors will be about 25 percent, and will rise to about 35 percent by the turn of the century. The share of LNG allocated to the power generation sector, on the other hand, is projected to increase to 25 percent by the early 1990 s, and to 34 percent after 1995. The remaining balance will be supplied to industrial consumers as fuel and/or feedstock. These shares translate into demand volumes of 1.4 billion $\mathrm{m}^{3}$ for power generation in the second half of the $1990 \mathrm{~s}$, and $0.7-1.5$ billion $\mathrm{m}^{3}$ for the residential and commercial sectors between 1990 and 2000. Official projections shown in Table 2.4 are likely to show the lower boundary of possible LNG demand since they do not take into account the postponement of two nuclear power plants announced in late 1988 , or the possible downward revision of coal use in the power sector.

It is unlikely that compensation for postponed nuclear power plants will be achieved through intensified capacity utilization of coal-fired plants. Burning approximately 30 million tonnes/year of additional coal not only would cause significant additional environmental pollution, but also involve additional imports, requiring the construction of new receiving, handling, and transportation facilities. Given the current 
Table 24

Projection of Natural Gas Supply \& Demand in Taiwan: 1987-2000 (mill. m3)

\begin{tabular}{|c|c|c|c|c|}
\hline & 1987 & 1990 & 1995 & 2000 \\
\hline \multicolumn{5}{|l|}{$\begin{array}{l}\text { SUPPLY } \\
\text { - Indigonous }\end{array}$} \\
\hline Production & 1,056 & 1,202 & 1,240 & 1,310 \\
\hline - Imports & 0 & 1,657 & 2,841 & 2,241 \\
\hline (LNG equin. '000 tonnes) & 0 & 1,184 & 2,101 & 2,101 \\
\hline TOTAL SUPPLY & 1,056 & 2,859 & 4,181 & 4,251 \\
\hline \multicolumn{5}{|l|}{ DEMAND } \\
\hline - Tal Power Corp. & 0 & 710 & 1,420 & 1,420 \\
\hline - Chinese Petroloum Corp. & 0 & 803 & 847 & 244 \\
\hline - Foodetock & 293 & 354 & 429 & 429 \\
\hline - Induatrial Fuel & 198 & 260 & 401 & 642 \\
\hline - Residential \& Commercial & 567 & 732 & 1,084 & 1,516 \\
\hline TOTAL DEMAND & 1,056 & 2,859 & 4,181 & 4,251 \\
\hline
\end{tabular}

Source: Chinese Petroleum Corporation, 1987. 
public opposition to new coal plants, the potential for increased natural gas/LNG use because of its clean-burning qualities becomes even greater. Thus the official projections are regarded as too conservative. Total LNG requirement in Taiwan could be as high as 2.5 million tonnes/year by the mid-1990s, and will probably reach 3.5 to 4 million tonnes/year by the turn of the century.

\section{PROSPECTIVE AND TENTATIVE PROJECTS}

In the past, a number of new projects have been proposed and discussed. However, few of these are likely to be realized during the remainder of this century. This section gives an overview of current proposals and their prospects for realization.

Alaska: The Alaska LNG export scheme utilizing Prudhoe Bay natural gas has been discussed over a long period of time. More recently, Yukon Pacific and Arco have proposed a new plant with a design capacity in the range of 7 to 14 million tonnes/year to be located on the Kenai Peninsula. Target markets for this US\$10 billion project are Japan, Korea, and Taiwan. A possible start-up has been projected for as early as the mid-1990s. ${ }^{45}$ However, the realization of this project depends on the willingness of potential buyers to follow promoters' demand for their participation as equity shareholders.

Indonesia: In Indonesia, following the discovery of substantial natural gas reserves offshore Natuna Island, a new LNG export scheme has been suggested. The 
estimated cost for a new plant capable of producing 9.1 million tonnes of LNG/year is in the vicinity of US\$8.0 billion." Originally, Japan, Korea, Taiwan and Singapore were targeted as potential customers. However, with Singapore and Malaysia reaching an agreement calling for pipeline delivery of natural gas, only Japan, Korea, and Taiwan remain as potential customers. The existence of a high ratio of inert gases (70\% and more $)^{47}$ will significantly increase processing and liquefaction costs, unfavorably influencing the competitiveness of Natuna Island-based LNG exports. For this reason, many industry sources regard internal utilization of these reserves as the more likely development. ${ }^{48}$ However, even if a new plant is built, the first drops of LNG from this facility are not likely to reach the market before the late 1990 s.

Malaysia: Malaysia has been negotiating with Korea for the delivery of 1.5 million tonnes/year of LNG. Although no firm commitments have been reached, talks are continuing according to recent reports. ${ }^{\$}$ However, at this early stage, no detailed information is available on likely contract terms.

Additional negotiations are in progress with Taiwan. Again, available information is rather scarce, although Japanese shipyards have confirmed that they are currently constructing a $136,000 \mathrm{~m}^{3} \mathrm{LNG}$ tanker, to be used to carry LNG from Malaysia to Taiwan. ${ }^{50}$ The size of the tanker under construction suggests annual contract volumes in the range of 1.5 to 2.0 million tonnes. Deliveries could commence during the first half of the 1990 s. 
Australia: In Australia, a contract for a third liquefaction unit for the North West Shelf Project has recently been negotiated. ${ }^{51}$ Two other proposals are still in the works. Elf Aquitaine Exploration Australia has proposed LNG exports based on its Tern (reserves of 34 to 51 billion $\mathrm{m}^{3}$ ) and/or Pertel fields (190-440 billion $\left.\mathrm{m}^{3}\right)$ that are located offshore the northern coast of Australia. Envisaged capacity is about 2.3 million tonnes/year. ${ }^{52}$ Elf Aquitaine suspended further work on the project in 1987 because of its perception of unfavorable market economics. The proposal has never been turned down officially and chances for its realization still exist. A realistic assessment suggests the earliest start-up as the end of the 1990s. More likely, operations will commence at the beginning of the next century, if at all.

A second LNG project has been proposed based on natural gas reserves discovered offshore Barrow Island. ${ }^{53}$ No information is available on possible capacity or startup. Again, operations cannot be expected to begin during the remainder of this century.

Abu Dhabi: Abu Dhabi has recently announced that a preliminary feasibility study is being conducted to assess the economics of doubling the capacity of its existing LNG plant. Tokyo Electric has reportedly expressed interest in buying the additional output. ${ }^{54}$

Canada: In Canada, Dome Petroleum proposed an LNG facility with a capacity of 3 million tonnes/year for export to Japan. In March 1982, contracts were drawn up 
between NIC Resources Inc. and Dome Petroleum as sellers, and Nissho Iwai, Chubu Electric, Kyushu Electric, Osaka Gas, and Toho Gas as buyers. ${ }^{3 s}$ However, with Dome Petroleum's financial problems becoming fully apparent at the beginning of 1984 , a long period of uncertainty with regard to the future development of this project ensued. The suspension of all negotiations was announced in 1986. As of early 1989, there has been no major change in the project status, and so the future prospects of the Canada LNG Co. do not look optimistic.

Soviet Union: Japanese utilities have also been discussing possible LNG export schemes with Soviet authorities for a long time. Talks first began, following the discovery of substantial natural gas reserves offshore Sakhalin Island. An LNG plant of 3 million tonnes/year capacity was proposed. The estimated costs of this facility were US\$3.8 billion. ${ }^{56}$ However, due to differences regarding project financing, as well as problems caused by the U.S. embargo following the Soviet invasion of Afghanistan, plans were delayed several times. In 1988, the project was revitalized again. Discussions are currently being held, ${ }^{57}$ but with the plans for pipeline exports of Soviet natural gas to Japan resurfacing, prospects for this LNG project are diminishing. ${ }^{58}$

There have also been negotiations between the Soviet Union, Japanese parties, and El Paso and Occidental Petroleum targeting an LNG export scheme in the Yakutsk region, located in eastern parts of the Soviet Union. Natural gas would be transported to the port of Olga via a $2,000-\mathrm{km}$ pipeline, where a gas liquefaction plant, capable of producing up to 7.5 million tonnes of LNG/year would be constructed..$^{59}$ 
However, diminishing U.S. interest led to the suspension of all negotiations, even though Japanese utilities have repeatedly expressed their interest in this project. As of early 1989 , no signs of progress were apparent. Hence, this project, should it ever materialize, will hardly have any implications for the regional LNG market before the late 1990 s or, more likely, the beginning of the next century.

Qatar: In Qatar, plans for exporting LNG from the massive non-associated gas reserves discovered in the Khuff Zone, offshore the northern coast, have been discussed. According to a three-phase plan developed for the utilization of these reserves, 6 million tonnes of LNG/year are to be exported. ${ }^{.0}$ The companies engaged in this US\$4-6 rillion project are Qatar General Petroleum Corporation (QGPC), which has a 77.5 percent share, and BP, CFP, and Marubeni, each with 7.5 percent. Reportedly, potential customers in India, Japan, Korea and Taiwan have shown interest in this LNG project, although no firm commitments have been reached. Provided that contracts can be negotiated, deliveries could begin by the mid-1990s, although, according to official statements, realization of this project is likely to be postponed, probably into the next century. ${ }^{61}$

China: In China, the discovery of substantial natural gas reserves (90-104 billion $\mathrm{m}^{3}$ ) offshore the southern coast of Hainan Island in the South China Sea by Arco China Inc. and China National Offshore Oil Corp. (CNOOC) has led to a proposal envisaging a new LNG export project. Reportedly, 3.25 billion $\mathrm{m}^{3} / \mathrm{year}$ of natural gas 
are to be produced, 50-60 percent of which is to be liquefied for export to Japanese customers. As of late 1988, Nissho Iwai was negotiating sales of up to 1 million tonnes of LNG/year to several Japanese utilities and had expressed optimism in reaching final agreements. To date, negotiations have not been finalized. ${ }^{62}$

The preliminary arrangements are particularly interesting because the proposal includes partial indexation of the LNG price to coal prices rather than to crude oil prices. If the proposed project comes to fruition and contracts include such pricing principles, this will be the first LNG contract in the region that links LNG prices to an energy source other than crude oil. This development could introduce more flexibility into LNG contracts; a move which has been long requested by Japanese buyers.

Papua New Guinea: The International Petroleum Corporation of Papua New Guinea (PNG) has discovered natural gas reserves in the Gulf of Papua that it claims is the biggest find worldwide since the early 1980s. Liquefaction trains and related facilities are to be built on mainland PNG. Although target markets are those of Asian countries, with Japan being the major potential cusiomer, no further information on this proposed project is available. As of end-1988, Japan had expressed interest in purchasing smaller volumes of PNG LNG, although no figures were given. ${ }^{63}$

New Zealand: In New Zealand, following the discovery of the Maui gas fields in 1969, a Shell-BP-Todd consortium proposed a LNG export scheme in 1979, with Japan as the main target market. ${ }^{\text {ot }}$ The project was shelved due to insufficient economic 
justification. Table 3.1 shows prospective and tentative LNG projects originating and/or ending in the Asia-Pacific region.

\section{LNG CONTRACTS: STABILITY VERSUS FLEXIBILITY}

Since the first LNG deliveries from Alaska to Japan were negotiated, supplies in the Asia-Pacific LNG trade have been delivered under long-term contracts with prices being indexed in various ways to crude oil prices. In addition, take-or-pay obligations have usually been in the range of 3 to 10 percent of annual contract volumes.

However, during the past few years, along with the request of customers for increased flexibility in LNG contracts, several agreements featuring significant differences from the previous arrangements have been reached. The recent contract between the Chinese Petroleum Corporation (CPC), Taiwan, and Pertamina, for instance, calls for take-or-pay obligations of only 64 percent during the buildup period. Furthermore, it appears to be the first contract in the Asia-Pacific that includes annual "allowances" that actually increase contract flexibility. ${ }^{6 s}$

There have been a number of other changes in LNG contracts, including shortterm arangements and alternative pricing formulas. With an increasing number of LNG plants being fully amortized, long-term contracts that were formerly regarded as vital in LNG trades lose some of their significance. For exporters, who have operated plants for nearly two decades, guaranteed long-term sales in terms of volumes also seem less important. Algeria has agreed to a one-year contract to deliver 220,000 tonnes of LNG to Tokyo Gas and Osaka Gas during 1989. Chubu Electric and Osaka 
Table 3.1

Tentative and Proepective LNG Plants Originating

and/or Torminating in Aola-Pacific

\begin{tabular}{|c|c|c|}
\hline Exporter & Importer & $\begin{array}{c}\text { Volume } \\
\text { (mill. tonnes/year) }\end{array}$ \\
\hline $\begin{array}{l}\text { Indoneala } \\
\text { (Natuna) }\end{array}$ & $\begin{array}{l}\text { Japan; Talwan } \\
\text { Korea; Singapore }\end{array}$ & 9.1 \\
\hline Malaysla & $\begin{array}{l}\text { Korea } \\
\text { Talwan }\end{array}$ & $\begin{array}{c}1.5 \\
1.5-2.5\end{array}$ \\
\hline $\begin{array}{l}\text { USA } \\
\text { (Alaska) }\end{array}$ & $\begin{array}{l}\text { Japan; Talwan } \\
\text { Korea }\end{array}$ & $7.0-14.0$ \\
\hline Canada & Japan & 3.0 \\
\hline $\begin{array}{l}\text { USSR } \\
\text { - Sakhalin } \\
\text { - Yakutak }\end{array}$ & $\begin{array}{l}\text { Japan } \\
\text { Japan/USA }\end{array}$ & $\begin{array}{l}3.0 \\
7.5\end{array}$ \\
\hline Qatar & $\begin{array}{l}\text { Japan; Talwan } \\
\text { Korea } \\
\text { Indla }\end{array}$ & 6.0 \\
\hline Abu Dhabl & Japan & 2.0 \\
\hline $\begin{array}{l}\text { Australla } \\
\text { - Portol }\end{array}$ & & 2.3 \\
\hline - Barrow Ioland & f Japan; S.K.i Taiwan & n.a. \\
\hline China & Japan & $1.2-1.4$ \\
\hline Papua Now Gulnea & n.a. & n.a. \\
\hline New Zealand & n.a. & n.a. \\
\hline $\begin{array}{l}\text { TOTAL TENTATIVE \& } \\
\text { PROSPECTIVE CAPACITY }\end{array}$ & & $44.1-52.3$ \\
\hline
\end{tabular}

Source: Compiled by the author. For detalled sources see Part 3. 
Gas have reached agreements with periods of three and five years, respectively. With regard to the proposed LNG scheme in China, partial price indexation to coal prices has been suggested.

Despite the new influx of short-term contracts, long-term sales will remain a standard contract feature since they remain crucial to the viability of new projects. On the other hand, consuming countries, especially Japan, are requesting increased flexibility, both in terms of annual delivered volumes as well as pricing and related aspects. Given the fact that long-term LNG prospects in consuming countries largely depend on competitiveness with other energy sources, changes in contracting practices seem to be inevitable. However, taking into account concerns about supply security for importing countries, it does not appear to be very likely that the majority of contracts will be on a short-term basis. As a result, a two-tiered system could evolve with longterm contracts being signed for volumes delivered from new plants, while some renewals of older contracts or the delivery of surplus production may be agreed on for shcrter periods.

Although it has been concluded that the number of short-term contracts in the regional LNG trade may increase in the future, particular features of LNG markets have to be borne in mind when dealing with probable future developments. Unless fundamental changes in the technical and economic parameters take place, spot trade of LNG similar to that of crude oil and/or petroleum products cannot develop. Loading, unloading, and storage capacities exist in only a few countries. Furthermore, the predominance of LNG utilization for power generation (intermediary and base 
load) is likely to limit substantial variations in demand. As stated above, this does not mean that comparatively short-term trades will not materialize. On the contrary, an increasing number of such trades is likely to be agreed on simply because more flexibility in contract duration is required in order to further increase regional LNG trade.

\section{CONCLUSIONS}

LNG trade in the Asia-Pacific is standing at the crossroads. Demand for LNG in the region can be expected to increase substantially until the turn of the century and thereafter. By the year 2000 , LNG demand is likely to be in the range of 51 to 56 million tonnes/year, with Japan accounting for 44 to 48 million tonnes/year, Korea 3 to 4 million tonnes/year, and Taiwan 3.5 to 4 million tonnes/year. This implies additional LNG deliveries for the Asia-Pacific region of about 10 to 15 million tonnes/year, compared with 1987 import volumes of 40.6 million tonnes. ${ }^{66}$ On the supply side, numerous LNG projects have been discussed. Output from these amounts to additional supplies of about 44 to 52 million tonnes/year. However, only a few projects are currently in a stage that could lead to start-up during the remainder of this century, but excess capacity in existing plants is estime ed to be about 4 to 5 million tonnes/year. This indicates that additional demand could be met with the realization of only a few major new projects.

Looking at the prospective demand-supply situation from the standpoint of individual consuming countries, the conclusion has to be somewhat modified. Japan, as 
the major consumer, is likely to witness the weakening of its bargaining position, even though this position is not likely to be altered substantially with the emergence of two additional buyers. As the biggest part of additional demand is projected in Japan, Japanese utilities must start negotiations at the beginning of the 1990 s in order to secure adequate supplies. In Korea and Taiwan, demand could grow at much faster rates than currently projected if the experience of the first years of LNG imports is regarded as positive. If current plans are to be realized, however, both countries will also need to secure additional supplies at the beginning of the 1990s. Furthermore, new receiving and related facilities will have to be constructed to handle these volumes.

The 1990s are likely to produce a series of new LNG contracts concerning the Asia-Pacific region. In order to take maximum advantage of the region's natural gas reserves and those elsewhere, consuming countries will have to understand the numerous constraints under which new LNG projects have to operate. On the other hand, the exporting nations will have to increase LNG's competitiveness in the consuming countries. Not only a more competitive and market responsive pricing basis has to be explored, but also all other major contractual clauses will need to be reconsidered in order to maintain and/or increase LNG's share in the region's energy markets. In fact, LNG's future prospects in the Asia-Pacific region mainly depend on the degree of flexibility introduced into contracts in upcoming negotiations. If these requirements are taken into consideration, and contractual relations between exporting and importing countries are altered, the future of LNG in the Asia-Pacific region can be judged with optimism. Increased flexibility in LNG contracts is important to further the market 
penetration of natural gas. As an alternate fuel, LNG use can contribute to supply security in the importing countries that depend on energy imports, particularly on oil imports from OPEC. Furthermore, LNG's quality as a clean fuel, is an important consideration in policy deliberations on energy security and environmental protection in the major energy consuming countries of the region. 


\section{NOTES}

1. Cedigaz, Natural Gas in the World in 1987, Paris: Cedigaz, 1988.

2. The natural gas markets are clearly defined as three regional markets: North America, Europe, and the Asia-Pacific. Each of these regional markets have their own distinct characteristics, problems, and prospects. This paper discusses the Asia-Pacific market and its unique aspects.

3. Cedigaz, see note 1 .

4. M.W.H. Peebles, Evolution of the Gas Induswy, New York: New Yort University Press, 1980, p. 109; Gerald B. Greenwald, "Japanese LNG Contracts", Oil and Gas Low and Taxation Reviav, vol. 10, 1983/1984, pp. 222.

5. Fereidun Fesharaki and Wendy Schultz, "Oil and Gas Trade in the Pacific Basin"; in Charles $\mathrm{K}$. Ebinger, and Ronald $\mathrm{A}$ Morse, (eds.), "U.S. Japanese Energy Relations - Cooperation and Competition," Boulder, Cotorado: Westview Press, 1984, p. 71; Peaoleum Economist, "World Survey Liquefied Natural Gas," December 1988.

6. Peebles, see note 4.

7. Greenwald, see note 4, p. 223.

8. Greenwald, see note 4, p. 223.

9. Fereidun Fesharaki and Wendy Schultz, see note 5, p. 69; Brunei Shell Petroleum Corapany Ltd., Brunei LNG, Brunei: Trade Relations Department, Brunei Shell Petroleum, 1980, pp. 9-12.

10. Petroleum Economist, January 1987, p. 41; Petromin, idarch 1987, p. 22.

11. Fereidun Fesharaki and Wendy Schultz, see note S, p. 69.

12. Fesharaki and Schultz, see note 5.

13. Fereidun Fesharaki and Wendy Schultz, "Natural Gas Supply and Demand Planning in the Asia-Pacific Region", Annual Review of Energy, Vol. 10, 1985, pp. 489.

14. Cedigaz, Intemational Trade of LNG, Paris, 1988, p. 70.

15. Pertamina, Hands Acrass the Sea - The Siony of Indonesian LNG, Jakarta: Pertamina, 1985, p. 51; Greenwald, see note 4, p. 224.

16. Platt's Oilgram News, 13 February 1989, pp. 2-3; Oil and Gas News, 20-26 February 1989, p. 12.

17. Pertamina, sec note 15, p. 50.

18. Pertamina, see note 15, p. 121.

19. Hutapea, R.O., "Financing of Natural Gas Export Projects in Developing Countries -The Indonesian Experience," paper presented at the "Eighth International Conference on Liquefied Natural Gas," $15-19$ June 1986, Los Angeles, U.S.A., p.11; Pertamina, see note 15, p. 126.

20. Pertamina, see note 15, p. 133.

21. Petroleum Economish October 1987, p. 385.

22. Saeed Taeb and Fereidun Fesharaki, The Asia-Pacific Petrolewn Report: Summary of Imponanu Developments, 3rd Quarter 1988, Energy Program, Resource Systems Institute, East-West Center, Honolulu, Hawaii, October 1988, p. 29. 
23. Petronas, A Decade of Malaysia's Petroleum Industry, Kuala Lumpur. Petronas, 1984, p. 14.

24. Petronas, Malaysia LNG. A Giant Project comes to Fruition, Supplement to Nada Petronas, February 1983 , p. 26.

25. Platt's Oilgram News, 29 November 1988, p. 5.

26. D.C.K. Allen, "Implementation of the Australian North West Shelf Project," paper presented at the "Eighth International Conference on Liquefied Natural Gas" (LNG 8), 15-19 June 1986, Los Angeles, USA; Parker, D.C., "Development of Western Australian Gas Resources," paper presented at the "13th Intemational LNG/LPG Conference \& Exhibition" (Gastech 88), 18-21 October, 1988, Kuala Lumpur, Malaysia.

27. Petroleum Intelligence Weekhy, 2 July 1984, p. 6.

28. Allen, see note 26, p. 6 .

29. These contracts are delivery of 2 million tonnes/year from Abu Dhabi to Tokyo Electric, and 0.7 million tonnes of excess production in Badak and Arun to Chubu Electric, Kansai Electric, and Kyushu Electric (see Tables 1.1 and 1.2).

30. Platt's Oilgram News, 3 August 1984, p. 3; Pertamina, see note 15, p. 136.

31. Petroleum Economist, "World Survey Liquefied Natural Gas," December 1986.

32. Pertamina, see note 15, p. 136; Petrolewn Intelligence Weekly, 8 August 1983, p. 8; 17 February 1986, p. $11 ; 16$ February 1987 , p. 7.

33. Platt's Oilgram News, 13 February 1989, pp. 2-3; Oil and Gas News, 20-26 February 1989, p. 12.

34. Petroleum Inselligence Weekly, 27 April 1987, p. 6.

35. Petroleum Economist, September 1987, p. 349.

36. Todd Johnson, David Fridley, and Wu Kang, "Taiwan - An Enengy Sector Study," Energy Program, Resource Systems Institute, East-West Center, Honolulu, Hawaii, 1988, p. 82.

37. Cedigaz, see note 14 , p. 92.

38. Ministry of International Trade and Industry (MITI), Long-Tem Enengy Supply and Demand Oulook, Tokyo: MITI, 14 October 1.987.

39. Fereidun Fesharaki, "LNG Demand in Asia : Even Better Prospects," Petroleun Advisory, No. 33, Energy Program, Resource Systems Institute, East-West Center, Honolulu, Hawaii, 10 November 1988.

40. N. Umekawa, M. Kawashima, T. Kobayashi, and Y. Nakamura, "Coastal LNG Transportation," paper presented at the "13th International LNG/LPG Conference \& Exhibition" (Gastech 88), 18-21 October 1988, Kuala Lumpur, Malaysia.

41. The Japan Economic Review, Vol. 21, No. 2, 15 February 1989, p. 11.

42. Korea Energy Economics Institute (KEEI), Enengy Future for Korea -Long-Term Oullook and Strategies: 1987-2010, Seoul: KEEI, 1987.

43. Oil and Gas News, 31 October-6 November 1988, p. 6.

44. Chinese Petroleum Corporation (CPC).

45. J. Horn, "The USA as a Major LNG Exporter - A future Scenario?," paper presented at the "13th International LNG/LPG Conference \& Exhibition" (Gastech 88), 18-21 October 1988, Kuala Lumpur, Malaysia. 
46. Joint Indonesian-German Research Project, (BPPT, Agency for the Assessment and Application of Technology/KFA, Kernforschungsanlage Jülich, GmbH), "Energy Strategies, Energy R\&D Strategies, Technology Assessment for Indonesia. The Indonesiun Gas Sector," 1988, pp. 67.

47. Joint Indonesian-German Research Project, see note 46, p. 65.

48. Cedigaz, see note 14, p. 110.

49. Oil and Gas News, see note 43, p.2.

50. Oil aurd Gas News, see note 49.

51. Plat's Oilgam News, 14 March 1989.

52. Petroleum Economis, April 1987, p. 127.

53. D.C. Parker, see note 26.

54. Platt's Oilgam News, see note 51.

55. Fereidun Fesharaki and Wendy Schultz, see note 5, p. 77; Greenwald, see note 4, p. 227.

56. Pebroleum Intelligence Weekly, August 1984, p. 6; Pedroleum Economirs, September 1984, p. 356; Fereidun Feaharald and Wendy Schultz, see note 5, p. 75.

57. Petroleum News, June 1988, p. 10.

58. Cedigaz, see note 14, p. 108.

59. Fereidun Fesharaki and Wendy Schultz, see note 5, p. 75.

60. Petrolewm Intelligence Weekty, 28 February 1983, p. 6; 9 April 1984, p. 8.

61. Petroleum Economist, January 1988, p. 27.

62. Asian Wall Street Joumal, 30 September-1 October 1988, FP. 1.

63. Petroleum Economist, see note 31, p. 393.

64. Cedigaz, see note 14 , p. 110.

65. Cedigaz, see note 14, pp. 91. "Allowances" have been agreed on in the Canadian LNG contract. However, this contract never materialized.

66. Cedigaz, see note 14. 

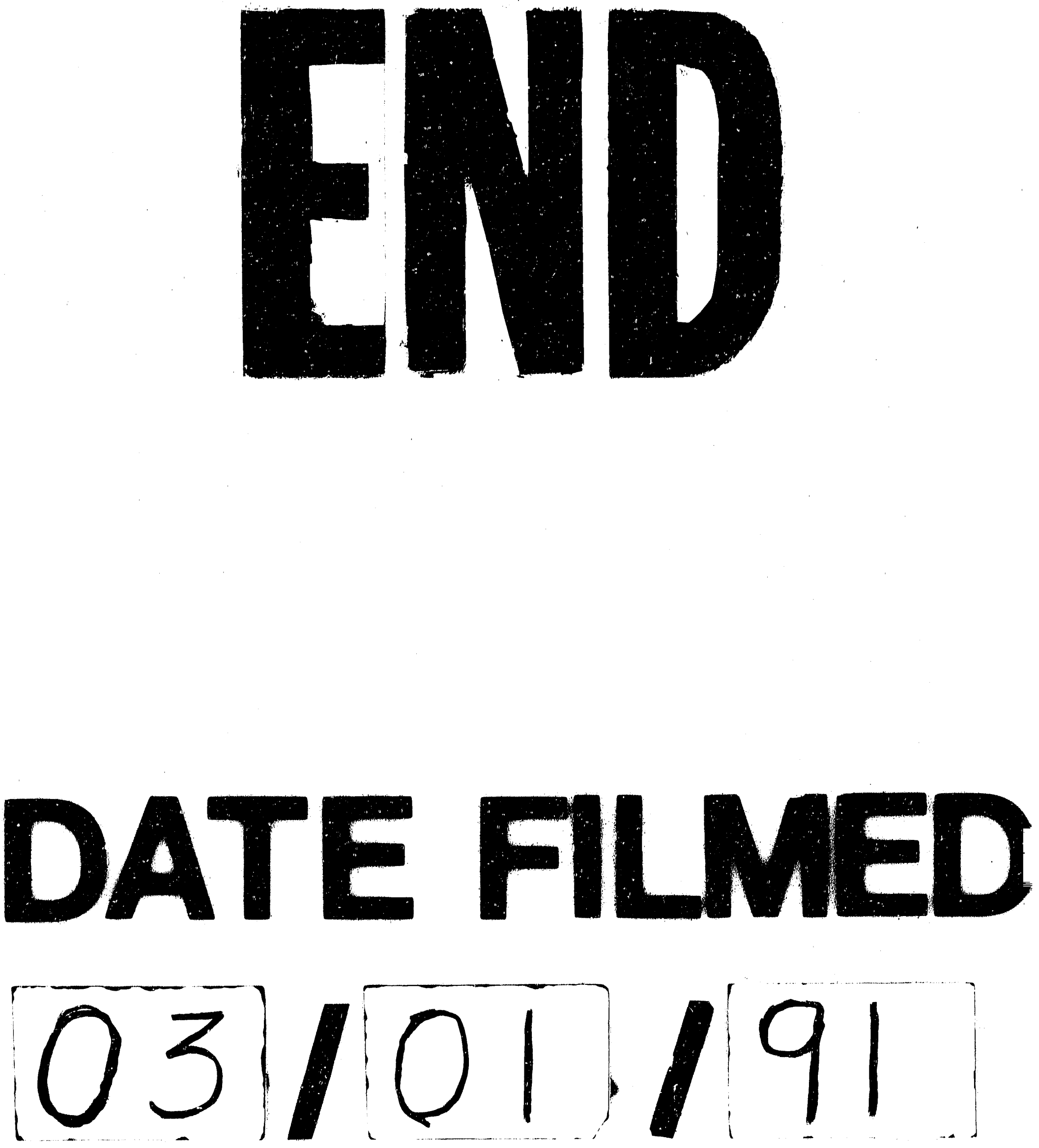
